DOI: https://doi.org/10.3126/jbssr.v5i2.35232

\title{
An Analysis of the Perceptions of Regulatory Authorities about the Causes of Non-Performing Loans
}

\section{Seema Bhattarai ${ }^{1}$}

Article History

Received 05 June 2020

Reviewed 12 July 2020

Revised 25 Oct 2020

Plagiarism Checked

2 Oct 2020

Revised 15 Oct 2020

Accepted 24 Oct 2020

Keywords

bank and financial institutions, non-performing loan, performing loan, regulators

Journal of Business and Social Sciences Research (ISSN: 2542-2812). Vol V, No. 2, Dec 2020

\section{Abstract}

The purpose of this study is to identify the causes of non-performing loans (NPAs) from regulators' perspective and ways to minimise it. The primary data through two interviews from two regulators are taken as a method of data collection. The major findings of the study are that pressure to remain profitable by banks, personal problems; lack of best banking practice, professionalism, earthquake, conflict period, economic cycle may be the reasons behind high non-performing loan in Nepal. Regulators perceived that prudent credit assessment and decision; counselling of customer problem and development of prudent credit culture may help to reduce non-performing loans in Nepal.

\section{Introduction and Study Objectives}

Non-performing loans (NPLs) are bad or impaired loans. The definition of nonperforming loans varies globally (Bhattarai, 2014). In context of Nepal, the Central Bank of Nepal (Nepal Rastra Bank, is a regulatory financial institution of the country. It has classified the loan basically into the pass loan, sub-standard loan, doubtful loan and loss or bad loan. Pass loan is defined as that type of loan the interest or principal payments of which are less than three months in arrears. The sub-standard loans are those type of loans whose interest or principal payments are longer than three months in arrears of lending conditions are eased. Doubtful loan is that type of the loan whose payment is due from 6 months to one year and its accounts suggest that there will be a loss, as well the exact amount of which cannot be determined. Loss loans are regarded as the non-collectable loans These loans are applied for legal resolution and protection using bankruptcy laws. Pass loans are categorised as performing loans whereas sub-standard loan, doubtful loan and loss loan are categorised as the nonperforming loans (Nepal Rastra Bank, 2013).

${ }^{1}$ Ms Bhattarai is an MPhil Student at KUSOM, Nepal. She can be reached at seemabhattarai1@ gmail.com 
The banking sector represents important sector within the service sector of the Nepalese economy. The contribution of bank and financial institutions to Gross Domestic Product (GDP) of Nepal is 18\% in FY 2075/76 (Regmi, 2020). Wellfunctioning banking sector helps to accelerate economic growth (Richard, 2011). On the contrary, if there is poor functioning banking sector, it creates an hinderance to the progress of the nation's economy. Hence, it implies that economic growth in any country is impossible in the absence of a sound banking sector (Rajaraman\&Vashistha, 2002). Khan and Senhadji (2001) argued that the well -functioning of banking sector is an indicator of prosperity and economic growth of any country.

The overall volume of credits of Nepalese commercial banks amount to 2629.837 billion rupees whereas the total deposits have reached to 2974.212 billion rupees (NRB, 2019). Based on the traditional role of bank, banks' assets constitute the bulk of loans (Njanike,2009). Havrilesky and Boorman (1994) pointed out that interest on loans are significant portion of income of banks (Reed \& Gill, 1989). So, in terms of banks' assets and income, the significance of lending for banks can be assessed However, the lending process is quite complex. It requires banks to examine the creditworthiness of customers and their ability to repay the principal and interest on time (Rajha,2016). This is because these lending procedures do not always lead to a successful transaction. At times one cannot know what will happen in the future. Sometimes, $\mathrm{n}$ future, if loans cannot be collected on due date, it may create a big problem for banks. And it is called non-performing loans (Chhimpa, 2002, as cited in Upal, 2009). In case of Nepalese commercial banks, the total volume of non-performing loans is 28.86 billion in mid-July 2017 . It comprises 1.70 percent of total outstanding loan and advances. As well, the non-performing loans of private sector banks has increased to Rs. 18.25 billion and that of public sector banks increased to Rs. 11.63 billion. The increment rate of non-performing loans of private sector banks was 8.27 percent whereas that of public sector banks was 7.93 percent (NRB, 2018). Since non-performing loan is increasing in case of Nepal and finding the causes of non-performing loan may help to reduce it. If the Bank and Financial Institutions (BFIs) of nation has low NPL, it will help in the increment of profit of BFIs, thereby improving the nation's economy. Therefore, examining the factors determining non-performing loan, also known as problem loan, in Nepalese banking sector, is an important issue for the research study. So, the objective of the study is to identify the causes and solutions of non-performing loans in Nepalese commercial banks from the perspective of regulators.

\section{Literature Review}

\subsection{Theoretical framework}

Macroeconomic theory states that there are two extreme economic situation, namely expansionary and recession (declining). The expansionary situation generates an optimistic environment whereas recession may create pessimistic 
environment in the nation's business (Mankiw, 2011). That is why, the probability that business people will demand more credit for their investment activities and repay on time is high during the expansionary phase while the chance that may be reluctant to invest and reduce the demand of credit and be unable to pay on time is high during contractionary phase of the economy (Dash \& Kabra, 2010).

\subsection{Empirical Review}

The literatures on causes of non-performing loans have identified two major factors that cause non-performing loans namely microeconomic and macroeconomic (Chaibi, 2016). Micro-economic factors are also called bank specific determinants. The bank-specific(microeconomic) determinants are liquidity, non-interest income, ownership concentration, bank size, management efficiency, loan loss provision, and leverage, regulatory capital, funding costs, and profitability. However, country-specific determinants (macroeconomic factors) of problem loans include the economic growth, unemployment, inflation, lending rates, sovereign debt, interest rate and exchange rate. The existing studies examine determinants of impaired loans in different countries (Spain, Guyanese, Turkey, Tunisia, and Nepal, Greece, USA, Sub-Saharan African countries) and group of countries, i.e., GIPSI (Portugal, Italy, Greece, Ireland and Spain), and Euro area. These empirical literatures are reviewed under two major headings: International context and national context.

\subsubsection{Bank Specific Factors}

Some researchers (Berger \& DeYoung, 1997; Metin \& Ali, 2015; Louzis, Vouldis, \& Metaxas, 2012) found that cost efficiency is probably a major factor causing future impaired loans in US, Turkey, and Greece. Moreover, the researchers (Khemraj \& Pasha, 2009; Fofack, 2005; Jimenez \& Saurina, 2006; Zribi \& Boujelbène,2011; Abid, Ouertani, \& Zouari,2014) concluded that high interest rates increase NPL whereas the researchers (Khemraj \& Pasha, 2009) emphasised that leverage ratio tend to increase NPLs in Guyanese economy, SubSaharan African country, Spain, and Tunisia. Credit conditions were recognized as a substantial factor behind high NPLs by some researchers in Spain, and GISPI (Jimenez \& Saurina,2006; Castro,2013). Fofack (2005) emphasised undiversified environment as a major cause of NPLs in Sub-Saharan African Country. The determinants of non-performing loans were also studied in Tunisian banking sector (Zribi \& Boujelbène, 2011; Abid et al., 2014) which concluded that the major microeconomic determinants of impaired loans are the ownership structure, prudential regulation of capital, and profitability of banks in Tunisia.

\subsubsection{Macroeconomic Factors}

Some researchers (Fofack,2005; Khemraj \& Pasha,2009; Louzis et al., 2012; Castro, 2013; Zribi \& Boujelbène,2011; Abid etal.,2014) found that macroeconomic factors like GDP affect NPLs in Sub-Saharan African country, Guyanese 
economy, Greece, GISPI, and Tunisia. Similarly, other researchers identified real effective exchange rate as a cause of NPL in Guyanese economy, GISPI, and Tunisia (Khemraj \& Pasha,2009; Castro, 2013; Zribi \& Boujelbène,2011; Abid et al.,2014). Similarly, Louzis et al. (2012) have focused on unemployment rate the cause of NPLs in Greece. Inflation was identified as a major cause of NPL by some research scholars (Zribi \& Boujelbène,2011; Abid et al.,2014) in Tunisia. Furthermore, some researchers (Fofack,2005; Jimenez \& Saurina,2006; Louzis et al.,2012; Castro, 2013) identified the economic growth as a major factor of NPLs in Sub-Saharan African country, Spain, Greece, and GISPI.

\subsubsection{Researches in Nepal}

There have been few researches in Nepal in the field of non-performing loan. Some of the researchers have also found that GDP, interest rate and inflation rate affect NPLs, in case of Nepalese BFIs (Bhattarai, 2014; Koju, Koju, \& Wang,2018; Bhul, Khatri, Khadka, \& Dhakal, 2016). Koju et al. (2018) showed that NPLs have significant positive relationship with inefficiency, and a negative relationship with the GDP growth rate, capital adequacy, and inflation rate. Some of the researchers have found the negative relation between NPLs and profitability (Pradhan, 2014; Gnawali, 2018; Shrestha, 2010). Pradhan (2014) identified that improper credit policy, political pressure to lend, lack of supervision and monitoring, economic slowdown and over evaluation of collateral as the major causes of occurring NPLs.

There are abundant literatures exploring the causes of non-performing loans from the perspective of commercial bankers, but what the regulators of the country perceive the causes of non-performing loans remain unexplored. Had the causes of non-performing loan from bankers' perspective been sufficient, the commercial and public bankers would have worked on it and there would have been much less non-performing loans in BFls. So, the perspective of regulators who work on supervision and regulation of credit risk are vital as they do not focus on a single bank but all the BFls. They have crucial role in monitoring the non-performing loans in BFIs of Nepal through different mechanisms discussed later in the paper.

A regulatory agency is also known as regulatory authority, regulatory body or regulator. It is a public authority or agency that is responsible for exercising autonomous authority over some area of human activity in a regulatory and supervisory capacity. Nepal Rastra Bank (NRB) is the regulatory agency and it regulates the banking system of Nepal. It also functions as the government's central bank. The new Nepal Rastra Bank Act 2002 which replaces the erstwhile Act has ensured an operational autonomy and independence to the bank. The key objectives of NRB are to achieve price and balance of payments stability, manage liquidity and ensure financial stability, develop a sound payments system, and promote financial services (NRB, 2019a).

Under the bank supervision department of NRB, the employees perform a daily off-site supervision and regular on-site supervision at certain interval of all financial 
institutions. Nepal Rastra Bank has classified the loan basically into the following: pass loan, sub-standard loan, doubtful loan and loss or bad loan. Pass loan is the performing loan. It is that type of loan whose interest or principal payments are less than three months in arrears. Similarly, sub-standard loans are those loans whose interest or principal payments are longer than three months in arrears of lending conditions are eased. Likewise, doubtful loans are loans due from six months to one year. Similarly, loss loans are regarded as uncollectable loans which apply for legal resolution and protection under bankruptcy laws. Hence, according to NRB, sub-standard loans, doubtful loans and loss loans are the non-performing loans.

The main objective of the NRB regulator is to develop safe and sound financial system by sufficient amount of qualitative capital and risk management practices. Their intention is to ensure that each bank maintains a level of capital which,

i. is sufficient enough to protect its depositors and creditors.

ii. is commensurate with the risk associated activities and profile of the banks.

iii. enhance public confidence in the banking system.

Credit risk is the major risk that banks are exposed to during the normal course of lending and credit underwriting. High non-performing loans in banks will lead to banks not being able to pay interest to its depositors and finally, insolvency of banks and loss of confidence of public in banking system as a whole. Hence, the main objective of the regulator is to encourage the banks to manage credit risk in a prudent and effective manner.

Regulators need to observe the performing loans and non-performing loans of all the commercial banks and have to examine the causes of all the non-performing loans. Hence, a regulator in the supervision department has an overall view of the causes of non-performing loan. S/he has a complete view with regard to causes of non -performing loans. So, understanding the perception of regulators regarding the causes of non-performing loans will not only benefit all the financial institutions but also enhance the financial stability and prosperity of the nation. So, this study aims to explore the answers of the following questions which have remained unexplored till now:

$>$ What are the causes of NPL in the perception of regulators?

$>$ From the viewpoint of regulatory authorities, what processes in the banking institutions lead to the NPL?

$>$ From the perspective of regulatory authorities, how can financial institutions reduce the NPL?

\subsection{Non- performing loans in Nepal}

Nepal Rastra Bank is a regulatory authority of Nepalese Financial institutions. As a regulator, NRB controls foreign exchange; supervises, monitors, and governs 
operations of banking and non-banking financial institutions; determines interest rates for commercial loans and deposits; and also determines exchange rates of foreign currencies (NRB, 2019a).

Through the latest available data from Nepal Rastra Bank, the non-performing loans is increasing in private sector banks by $8.27 \%$ whereas in public sector banks by 7.93 percent (NRB, 2018). So, on average, non-performing loans is increasing by 8.10 percent in overall Nepalese banking sector.

When non-performing loan is high in banks and financial institutions, it leads to credit risk. In other words, credit risk is the likelihood that a debtor is unwilling or unable to pay interest or repay the principal according to the terms prescribed in a credit agreement resulting in economic loss to banks (NRB, 2019a). So, credit risk refers to the risk of negative effects on the financial result and capital of the bank caused by borrowers' default on its obligations to the bank (NRB, 2019a).

Credit risk results from bank's dealing with individuals, corporate, banks and financial institutions. It does not occur alone. So, the understanding of the causes behind the non-performing loans will not only cause the BFIs to prevent loss from NPLs but also help them avoid exposure to liquidity risk as well. Hence, the exploration of the causes of non-performing loans, its financial implications on BFIs and nations is a pertinent issue. Finding the ways to mitigate this credit risk is a concern.

Nepal Rastra Bank (NRB), the sole regulator of BFls in Nepal has recommended the fundamental credit risk management policies and practices to govern the implementation of lending procedures and practices within the banks (NRB, 2019a). So, for a credit risk management framework, the BFIs must have Board and Senior management oversight, Credit strategy, policies, procedures, limits and origination, Credit administration, Internal credit Risk Rating system, Credit risk monitoring and control, Credit risk review and Managing problem credits (NRB, 2019a). Despite this framework, NPL is still increasing and therefore, what contributes to the causes of NPL in Nepalese banking sector is yet to be known.

\section{Research Methods}

\section{Research Design}

Qualitative research methodology was used. This is because this study is intended to gain an understanding of underlying reasons, opinions, and motivations of regulators in the concerned area. It also helps to uncover the trends in thought and opinions and drive deeper into the subject matter, namely perception of nonperforming loans with regard to regulators. Similarly, the goal of understanding a phenomenon from the point of view of the participants is largely lost when textual data are quantified. So, the qualitative research categorised as interpretive is used with start out with the assumption that access to reality is only through social constructions where shared meanings is used. The interpretive research 
deals basically on the full complexity of human sense making when the situation emerges. Hence, this study was undertaken as an interpretive research effort to gain insight into the perceived causes of non-performing loans in Nepalese banking sectors by regulators. According to this approach, the researcher aims to describe the lived or heard experiences of the participants, without being influenced by any pre-given framework (Thomas, 2004). So, the purpose of the study is to identify perception of regulators regarding causes of non-performing loan and possible ways to reduce it.

\section{Research Strategy}

While conducting this study, the selected regulators were interviewed. They worked as an employee of regulatory department of central bank of Nepal. This study helps to generate data that will provide insights into the causes of NPL from the eye of regulators.

\section{Research setting}

The research setting and the physical outcome are important since they can influence the research outcome (King \& Horrocks, 2010; Terre Blanche, Durrheim, \& Painter, 2006). Due to this, a great care was taken to ensure that the interview location was comfortable, private and quiet.

\section{Participants and Sampling}

The study used a purposive, voluntary non-probability sampling method where two officials of the regulator organisation was selected for the study. The regulators were chosen from the employees of regulatory and supervision department of Nepal Rastra Bank. The sample contained two regulators, one worked in the department for 13 years and other worked in the department for 7 years. Both are highly experienced employees. Due to lack of time, the sample size is very small and sampling method is purposive.

\section{Data Collection Methods}

The data collection method used was a semi-structured individual interview for the research purpose. The informed written consent was taken before approaching the participants for the study. They were asked seven standard successive questions. The first question was the asked for the background of the study, i.e., "How many years did you worked as a regulator?" Then, others were -"what do you feel to media rumours as disclosed NPL do not reflect real NPL? What might be the reasons behind it? Is there any incident you remember regarding deal with NPL as a regulator? What do you feel when you see high NPL? What are the major causes of NPL from your perception? In your view, what might be the possible ways to reduce NPL? Even after strict regulation, why hasn't NPL declined to minimum?" The study sought participants' cooperation in elaborating their thoughts, feelings, opinions, experiences and perspectives. 


\section{Data Analysis and Discussions}

The data obtained through research interview was analysed by using content analysis. It is a systematic technique which collects and compresses large bodies of text into specific and identifiable content categories, so that data can be analysed easily (Hesse-Biber \& Leavy, 2004). The content analysis mainly deals with the content and contextual meaning of the text. Thus, it helps to get a valid inference, which is only possible through the review of interview transcribe several times.

\subsection{Key Findings}

Data analysis produced two major factors, bank specific and macroeconomic factors, which contribute to the increase in NPL of BFls in Nepal. They are summarised in figure below:

\begin{tabular}{|c|c|}
\hline \multicolumn{2}{|l|}{ Causes of NPL } \\
\hline Bank specific factors: & Macroeconomic factors: \\
\hline 1) Profitability drive & 1) Earthquake \\
\hline 2) Lack of Professionalism & 2) Economic cycle \\
\hline 3) Personal Problems & 3) Conflict period \\
\hline 4) Lack of best banking practice & \\
\hline Consequences of High NPL & \\
\hline 1) Loss of bank & \\
\hline 2) Reduction of government tax & \\
\hline 3) Doubt on regulatory authority & \\
\hline Solutions & \\
\hline 1. Prudent credit assessment and decision & \\
\hline 2. Counselling of customer's problem & \\
\hline 3. Development of prudent credit culture & \\
\hline
\end{tabular}

\subsubsection{Bank Specific Factors}

From the interview, it seems that the main factors leading to the increase of NPLs for BFls revolve around compromise in best banking practice and poor monitoring and tracking of loan customers.

\section{a. Lack of best banking practice}

According to regulators, best banking practice is another phrase for banking discipline. According to them, banking employees and loan customers, if adhere to banking discipline, NPL may be low. The loan customers' repayment of the loan on time and use of it for the purpose specified in loan contract are one side of best banking practices, according to regulators. Similarly, if loan officers identified, 
evaluated the loan borrowers and performed analysis of customers' capacity, it is the other side of the best banking practice. The best banking practice requires that loan officers are not negligent and are monitoring the stocks and receivables of borrowers on time. In the absence of this practice and discipline, there may be an increase in NPL, in the perspective of regulators.

Interviewee B:"One point is...loan is disbursed for one purpose and it is used for other purposes... Other is, we are not able to teach customers the banking culture... and, credit assessment regarding comprehensive analysis of customers' capacity and economic discipline is lacking.......well, the lending ability of the banks seem not being transparently communicated to the loan officers responsibly.... Lack of proper identification and evaluation of loan borrowers may also lead to high NPL. lack of close monitoring of stocks and receivables of borrowers and negligent feeling of banks that their work is only to grant loan since loan and advances show loan collection may also lead to NPL."

\section{b. Profitability drive}

There is always a pressure to remain highly profitable in the market. which is also termed as profitability drive. This is perceived as a contributing factor to increase NPLs by regulators. At the present scenario of BFIs, there is an intense competition among them. As per NRB regulation, the banks need to maintain high capital, they need to give high stable dividend return to gain the confidence of shareholders. For this, banks need high earning and profit. The major source of earning of banks is interest income from loan. So, the banks, in order to gain high income aggressively, may accept loans without proper investigation and evaluation, which in turn may lead to high NPL, according to regulators.

Interviewee A: "As per the perception of banks, there is a competitive market which has pressurised banks to remain profitable, to gain high capital through merger, and maintain stable dividend return. So, to manage the bank, in that scenario, the banks need to increase interest income through loan and advances. When the banks try to aggressively increase loan of bank only, NPL increases."

\section{c. Lack of professionalism}

The lack of professionalism of borrowers and bank employees may also be a reason behind high NPLs. Professionalism of the banks means abiding by the rules and regulations circulated by central bank of Nepal. Similarly, the customers are expected to repay the loan on due time. Hence, in the absence of professionalism in practice, NPL may be high, according to regulators.

Interviewee B: "Borrowers of loan need to have high level professional culture, which means the banks and customers, both, must maintain practice as expected by regulation and policy. If the bank's loan officers and customers neglect on these, NPL increases. 


\section{d. Personal problems}

Each loan customers of banks may have their own problems. Some may have market related problems, some may have management related problems, others may have tax related, labour related, and partnership related problems. So, if these problems remain unsolved, the loan borrowers may not be able to repay loan on time. This may also lead to high NPL, according to regulators.

Interviewee B: "Customers' problems are taken as ease, but sometimes, individual problems like market related, management related, tax related, labour related, partnership related and other may also lead to high NPLs."

\section{Macroeconomic Factors}

The macroeconomic factors that seem to influence NPLs are earthquake, economic cycle and political unrest as represented by conflict period in Nepal.

\section{a. Earthquake}

According to the perspective of regulators, among many macroeconomic variables affecting NPL, earthquake may be the one. On 2015 A.D., Nepal was hard hit by earthquake. Due to earthquakes, several infrastructures of business and their properties were collapsed. Hence, these loan borrowers have to suffer huge loss of income and were not able to pay loans. This may also lead to high NPL.

Interviewee A: "There was massive destruction due to the big earthquake in Nepal in 2015, when many businesses collapse. At that point of time, borrower was credit worthy, bank was also good and credit appraisal was also perfect. But, earthquake, an external cause, also led to NPL."

\section{b. Economic cycle}

Economic cycle, also known as business cycle, has a series of phases, i.e., boom, prosperity, recession and depression. Boom and prosperity are the phases in which the economic activities and businesses flourish, whereas recession and depression are the phases in which economic activities and businesses decline. So, when the economic activities decline, the businesses wouldn't be able to earn profitable amount to repay loan on time. Hence, it may also lead to high NPL.

Interviewee B: "Bank's NPL is linked with different phases of economic cycle. In other words, economic cycle is called business cycle, which fluctuates. Sometimes, when this cycle is at boom or prosperity, all business activities flourish, which will decrease NPL. While the economy is in downturn, business activities will decline and NPL will increase."

\section{c. Conflict period}

In Nepal, there was a conflict period due to Maoist party from 1995 A.D. to 2006 A.D. Due to safety reasons, the tourists were reluctant to visit Nepal. So, the 
tourism industry declined. Similarly, several infrastructures were damaged. There were series of strikes, war, and conflicts in all places of Nepal. This led to the decline in economic activities which caused loan borrowers to be unable to repay loan on time. So, it may lead to high NPL.

Interviewee B: "Apart from other factors, sometimes political conflict also causes high NPL.... NPL may also arise."

\section{Consequences}

When there is high NPL, it has many effects. At first, when the borrower is not able to pay the loan on time, the loan borrower is blacklisted. His/her property is auctioned. Similarly, the banks will have to increase its provisioning to 100 percent; hence banks' health will be poor as their earning will decline, when the banks' health decline, the banks may collapse, and the tax revenue of government will decline. Similarly, if a bank's NPL is high, it signals negative image of BFIs of the country, when the banks' NPL is increased, the regulatory and supervision department will be questioned on their jobs. Hence, high NPL is perceived as a loss to all stakeholders, i.e., banks, government, regulators, supervision department and customers, according to regulators.

Interviewee B: "There are multiple effects of NPL. For instance, when a loan becomes NPL, then the borrower's property will be auctioned and hence property will be gone.... On the other hand, when bank's NPL increases, provisioning also increases and bank will suffer from loss... Hence bank's health will be poor, which has negative spill-over effect on other banks also just as a rotten potato causes other potatoes in the sack to be rotten."

Interviewee A: "As provisioning of NPL increases, bank's profit declines, the tax revenue of government will decline...., bank's asset quality will also decline, there will be questioning on regulator and supervision. So, none of the stakeholder has desire for NPL or credit risk and provisioning."

\section{Solutions of high NPL}

The ways to reduce NPL may be prudent credit assessment and decision, counselling of borrowers' problem as well as development of prudent credit culture.

\section{a. Prudent credit assessment and decision}

According to the regulators' perspectives, if BFls have effective applications of policy, procedure and system, as specified by regulatory authority, it may reduce NPL. The activities from credit initiation to credit administration to disbursement and follow up, consists of borrower identification, assessment and collateral evaluation. So, if all these activities follow policy, rules and regulations by regulatory authority, the NPL may be low. 
Interviewee A: "Banks and Financial Institutions need to have strong corporate governance, which means, effective applications of policy, procedure and system, from credit initiation to credit administration to disbursement and follow up. This effective corporate governance may help to reduce NPLs. So, here, credit appraisal plays a vital role. It is also called loan appraisal, in broad sense, credit management. It involves borrower identification, assessment and collateral evaluation (asset quality). When banks compromise in these factors, NPL increases. So, effective and strong credit management (assessment and decision) play a vital role in the decrease of NPL."

\section{b. Counselling of customer's problem}

Each banks' loan customer may have problems, that is related to marketing, management, labour and taxes. A bank has to deal with a lot of customers, so, they are aware of these problems and possible solutions. So, according to regulators, the counselling of customers' problems by banks may help customers to repay loan on time, thereby causing a low NPL.

Interviewee B: "The bank has more loan exposure than individual customer. So, it is the responsibility of bank to timely counsel and suggest them regarding marketing, management, labour and other problems. Since a bank has to deal with several customers and their issues, so, the bank can give managerial tips to solve their problems, loan customers investing in small business don't have solution to their problems. Hence, the bankers' suggestions and counselling can be helpful."

\section{c. Development of prudent credit culture}

According to the regulators, the bank, if adopts a culture of monitoring whether the loan is used for the purpose as defined in contract, and customers, if adopt a culture of paying interest and principal on time, it may reduce NPL. Similarly, if it is made sure that regulatory guidelines, directives, policies, procedures and recommendations of on-site and off-site supervisions are implemented on time, it may also lead to low NPL.

Interviewee A: "Till the bank compromise with regulatory guidelines, regulatory directives, internal policy, procedure and best banking practice for loan initiation to collection, NPL will naturally increase. So, the loan officers should be updated about the system, policy, procedure, internal control system. The remarks from internal audits should be improved. Recommendation of on-site and off-site supervisions must be used in practice, the only NPL will decline."

Interviewee B: "When a banking culture of utilising loan for defined purpose and timely payment of loan is taught to credit customers, NPL declines. It is seen that customers have source and means to pay loans they took but they start a new business with it rather than paying the principle and interest of loan." 
Of the major factors mentioned, many of them are consistent with international and national literatures that are focused on certain factors like update with policies, practices, managing problem loans, and others. In previous studies by Osman and Vikenswaran (2017), the lack of BOD and senior management oversight on credit exposures, standard for loan collateral, loan review mechanism, risk and evaluation and pricing of loan have been indicated as possible causes of high NPL. This corresponds to the research finding called as professionalism, whose absence, is perceived as a reason behind high NPLs in Nepalese BFIs.

Similarly, Osman, and Vikneswaran (2017) highlighted that credit risk policies and strategies of BOD have to be informed senior management and loan officers to manage credit risks, these policies have to be embedded in the culture of organisation to reduce NPL. It is related to the absence of the best banking practice, which is perceived as the main cause of NPL, by regulators. As well, the organisation, if grants loan without assessing its lending capacity, NPL may increase (Hu et al., 2004). It can be related to the findings of the study which says that the proper assessment of its lending capacity may help to reduce NPL.

Furthermore, the lack of proper understanding of client, their credentials and their business problems may also lead to high NPL (Berger \& De Young,1997; Barth et al.,2002). This can also be aligned with the finding of research, labelled as personal problems. For instance, a loan borrower may have taken loan for some business projects. While launching these businesses, s/he has to face labour, tax, marketing, and other problems, if the loan is taken for personal purpose, s/ he may have to face personal family related problems. If these problems remain unnoticed and unmanaged, the loan borrower will not be able to repay loan on time. Hence, the loan becomes non-performing loan.

Under the problematic conditions of customers mentioned above as personal problems, if the bank counsels the loan customers about the probable solutions of their problems, they may be able to solve their problems and have earnings as expected of their projects. As a result, this may lead to decline in NPL. Thus, the finding suggests that regulators perceive management of problematic credits through counselling as fruitful, as it may also help to decrease NPL, which is in line with the existing literature by Osman and Vikneswaran (2017).

In addition, there is a need of a prudential system from credit initiation to disbursement to administration to minimise NPL (Berger \& DeYoung, 1997). This is also related to prudential credit assessment and decision, denoted as a solution of high NPL. Furthermore, Rajan (1994) specifies that there is a pressure to bank to remain profitable, which may also be reason behind high NPL. This also corresponds to one of the research findings, profitability drive indicated as a cause to high NPL, in regulators' view.

Reporting to BOD, reviewing on-site and off-site supervision may also help to reduce NPL which is also related to the existing literature (Van den Heuvel, 2002). For instance, as the regulators visit all the banks by on-site supervisions and 
observe these banks by off-site supervisions, they have a close view of NPL and its causes. So, the review of on-site and off-site supervision recommendation and its report to BOD timely may help to reduce NPL, as per the perspective of regulators.

Economic cycle, also known as macroeconomic factor as indicated by research finding, is also related to the existing literature by Salas and Saurina (2002). This can further be elaborated that economic downturn decreases economic activities and thereby increases NPLs.

However, earthquakes and conflict period are not noted as causes of NPL in previous studies. It is not surprising to find that the regulators perceive these factors (earthquake and conflict period) as causes of NPLs. This is because Nepal has gone through its phase of conflict period from 1995 A.D.to 2006 A.D. and earthquake in 2015 A.D. These events had negative effect in Nepalese economy which led to high NPLs.

\section{Conclusion and Implications}

There are many factors perceived as causing high NPL. Some of them are lack of professionalism and best banking practice. They are under the control of BFIs and are called bank specific factors. However, the other factors like economic downturns, earthquakes, and political conflict period are the external factors. The BFIs if have prudential credit assessment and decision, backed up by counselling of borrowers' problem may reduce NPL, as per the perception of regulators.

In addition, non-performing loan demands high provisioning, which consume high capital of the bank, thereby, decline the profit of the bank. This will also cause decrease in government tax revenue, auction of borrowers' property. So, according to the regulators, it may be fruitful to all stakeholders (BFIs, credit customers, and government), if the NPL or problem loan could be managed by converting it to performing loan with the support of banks to customers and best banking practice by customers.

There has been no exploration on the rumour if disclosed NPL represents real NPL. So, the regulator suggested that the evaluation of real NPL versus disclosed NPL could be fruitful to both the financial institutions and regulatory authorities. Hence, it indicates a future area of research.

\section{References}

Abid, L., Ouertani, M. N., \& Zouari, G. S. (2014). Macroeconomic and bank specific determinants of household's non-performing loans in Tunisia: A dynamic panel data. Procedia Economics and Finance, 13, 58-68. Retrieved fromhttp://dx.doi. org/10.1016/S2212-5671(14)00430-4

Barth, J. R., Dopico, L. G., Nolle, D. E., \& Wilcox, J. A. (2002). Bank safety and soundness and the structure of bank supervision: A cross-country analysis. International Review of Finance, 3(3-4), 163-188. Retrieved fromhttp://dx.doi. org/10.1111/j.1369-412X.2002.00037. 
Bercoff, J.J., Giovanniz, J.,\&Grimardx, F. (2002). Argentinean banks, credit growth and the tequila crisis: A duration analysis.

Berger, A.N., \& DeYoung, R. (1997). Problem loans cost efficiency in commercial banks. Journal of Banking \& Finance, 21, 849-870.

Bhattarai, S. (2014). Determinants of non-performing loans: perception of Nepali bankers. Economic Journal of Development Issues, 17\& 18(1-2), 128-148. Retrieved fromhttp://www.nepjol.info/index.php/EJDI/article/download/14524/11800

Bhul, B.S., Khatri, B., Khadka, K., \& Dhakal,S.(2016). Determinants of non-performing Ioan: Case of Nepalese Commercial Banks. School of Management Tribhuvan University, Kathmandu. Nepal.

Castro, V. (2013). Macroeconomic determinants of the credit risk in the banking system: The case of the GIPSI. Economic Modeling, 31, 672-683. Retrieved from http:// dx.doi.org/10.1016/j.econmod.2013.01.027

Chaibi, H. (2016). Determinants of problem loans: Non-performing loans vs. loan quality deterioration. International Business Research,9(10), 87-93.

Chhimpa, J. (2002). Incremental NPA: Stem that inflow, Vinimaya, 23(3), 18-21.

Dash, M. K., \& Kabra, G. (2010). The determinants of non-performing assets in Indian commercial bank: An econometric study. Middle Eastern Finance and Economics, 7, 94-106.

Dimitrios, A., Louri, H., \& Tsionas, M. (2016). Determinants of non-performing loans: Evidence from Euro-area countries. Finance Research Letters. Retrieved fromhttp://dx.doi.org/10.1016/j.frl.2016.04.008

Fofack, H. (2005). Non-performing loans in Sub-Saharan Africa: Causal analysis and macroeconomic implications. World Bank Policy Research Working Paper, 37-69.

Gnawali, A. (2018). Non-performing asset and its effects on profitability of Nepalese commercial banks. International Journal of Research in Business Studies and Management, 5(9), 39-47.

Hesse-Biber, S.N., \& Leavy, P. (2004). Approaches to qualitative research: A reader on theory and practice. Oxford, UK: Oxford University Press.

Hu, J., Yang, L., \& Yung, H. C. (2004). Ownership and non-performing loans: Evidence from Taiwan's banks. Developing Economies, 42, 405-420. Retrieved fromhttp:// dx.doi.org/10.1111/j.1746-1049.2004.tb00945.x

Jimenez, G., \&Saurina, J. (2006). Credit cycles, credit risk and prudential regulation. International Journal of Central Banking, 65-98.

Karim,M.Z.A., Chan,S.,\& Hassan,S. (2010).Bank efficiency and non-performing loans: Evidence from Malaysia and Singapore. Prague Economic Paper, 2, 118-132

Khan, M.S., \& Senhadji, S.A. (2001). Threshold effects in the relationship between inflation and growth. IMF Staff Papers, 48(1).

Khemraj, T., \& Pasha, S. (2009). The determinants of non-performing loans: An econometric case study of Guyana. The Caribbean Centre for Banking and Finance Bi-annual Conference on Banking and Finance.

King, E.C., \&Horrocks, C. (2010). Interviews in qualitative research. London, UK: Sage Publications.

Koju, L., Koju, R., \& Wang,S. (2018). Macroeconomic and bank-specific determinants of non-performing loans: Evidence from Nepalese banking system. Journal of Central Banking Theory and Practice, 7(3), 111-138. 
Louzis, D., Vouldis, A., \& Metaxas, V. (2012). Macroeconomic and bank-specific determinants of non-performing loans in Greece: A comparative study of mortgage, business and consumer loan portfolios. Journal of Banking and Finance, 36, 10121027.

Mankiw, N.G. (2011). Principles of macroeconomics (4thed.). New Delhi: Cengage Learning

Metin, V.,\& Ali, H. (2015). Determining impacts on non-performing loan ratio in Turkey. Journal of Applied Finance and Banking, 5(1), 1-11.

Nepal Rastra Bank.(2013). Unified directives. Kathmandu: Author.

Nepal Rastra Bank.(2018). Banking and financial statistics. Kathmandu: Author.

Nepal Rastra Bank. (2019). Bank supervision report. Kathmandu: Author.

Nepal Rastra Bank. (2019a). about us. Kathmandu: Author. Retrieved fromwww.nrb.org Njanike, K. (2009). The impact of effective credit risk management on bank survival. Annals of the University of Petroşani, Economics Journal, 9(2), 173-184.

Osman, H. H., \& Vikneswaran (2017). Non-performing loans: Perception of Somali bankers. International Journal of Advanced Research and Publication, 1(5), 205231.

Pradhan, K. (2014). A study on non- performing assets of commercial bank with references to SCBNL, RBB, Everest Bank, NB Bank and NBBL (Unpublished Master's Thesis). Tribhuvan University, Kathmandu, Nepal.

Podpiera, J., \& Weill, L. (2008). Bad luck or bad management? Emerging banking market experience. Journal of Financial Stability, 4, 135-148.

Rajan, R. (1994). Why bank policies fluctuate: A theory and some evidence. Quarterly Journal of Economics, 109, 399-441. Retrieved from http://dx.doi. org/10.2307/2118468.

Rajaraman, I., \& Vashistha, G. (2002). Non-performing loans of Indian public sector Banks: Some panel results. Economic \& Political Weekly.

Rajha, K. S. (2016). Determinants of non-performing loans: Evidence from the Jordanian banking sector. Journal of Finance and Bank Management, 4(1), 125136. Retrieved fromhttp://jfbmnet.com/journals/jfbm/Vol_4_No_1_June_2016/9.pdf.

Reddy, Y.V. (2004). Credit policy, systems, and culture. Reserve Bank of India Bulletin.

Reed, E., \& Gill, E. (1989). Commercial banking. New Jersey: Prentice Hall.

Regmi, D. (2020). Contribution of banking sector to the GDP of Nepal. Investopaper. Retrieved from https://www.investopaper.com/news/contribution-of-bankingsector-to-the-gdp-of-nepal/\#: :text=Imagine $\% 20 \mathrm{a} \% 20$ bank $\% 20$ that $\% 20 \mathrm{is}$,the $\% 20$ name\%20of\%20'Tax'

Richard, E. (2011). Factors that cause non- performing loans in commercial banks in Tanzania and strategies to resolve them. Journal of Management Policy and Practice, 12(7), 50-58.

Salas, V., \& Saurina, J. (2002). Credit risk in two institutional regimes: Spanish commercial and savings banks. Journal of Financial Services Research, 22(3), 203-224.

Shrestha, K. (2010). A study of Non- performing Loan and loan loss provision of commercial Banks, A case study of NIBL, HBL and EBL. Unpublished Master Degree Thesis Submitted to Tribhuvan University. 
Terre Blanche, M., Durrheim, K., \& Painter, D. (2006). Research in practice: Applied methods for the social sciences. Cape Town, South Africa: University of Cape Town Press.

Thomas, A.B. (2004). Research skills for management studies. London, UK: Routledge.

Upal, R.K. (2009). Priority sector advances: Trends, issues and strategies. Journal of Accounting and Taxation, 1(5), 079-089.

Van den Heuvel, S.J. (2002). Does bank capital matter for monetary transmission? Economic Policy Review, 259-265.

Zribi, N., \& Boujelbène, Y. (2011). The factors influencing bank credit risk: The case of Tunisia. Journal of Accounting and Taxation, 3(4), 70-78.

\section{Acknowledgements}

The author acknowledges the encouragement of Dr. Amina Singh.

Funding

The author received no funding or financial support in carrying out the research.

\section{Conflict of interest}

The author declares absence of conflict of her interest in the research work. 